\title{
Erythrina suberosa: Ethnopharmacology, Phytochemistry and Biological Activities
}

\author{
Felicia Patti ${ }^{1}$, Yasaman Taheri ${ }^{2,3, *}$, Javad Sharifi-Rad ${ }^{4, *} \mathbb{C}$, Miquel Martorell ${ }^{5,6} \mathbb{D}_{\text {, }}$ \\ William C. Cho ${ }^{7, * \mathbb{D}}$ and Raffaele Pezzani $1,8, * \mathbb{B}$ \\ 1 OU Endocrinology, Dept. Medicine (DIMED), University of Padova, via Ospedale 105, 35128 Padova, Italy; \\ feliciapatti@hotmail.com \\ 2 Phytochemistry Research Center, Shahid Beheshti University of Medical Sciences, Tehran 11369, Iran \\ 3 Department of Pharmacology and Toxicology, School of Pharmacy, Shahid Beheshti University of Medical \\ Sciences, Tehran 11369, Iran \\ 4 Zabol Medicinal Plants Research Center, Zabol University of Medical Sciences, Zabol 61615-585, Iran \\ 5 Department of Nutrition and Dietetics, Faculty of Pharmacy, University of Concepcion, Concepcion 4070386, \\ Chile; martorellpons@gmail.com \\ 6 Universidad de Concepción, Unidad de Desarrollo Tecnológico, UDT, Concepción 4070386, Chile \\ 7 Department of Clinical Oncology, Queen Elizabeth Hospital, 30 Gascoigne Road, Hong Kong \\ 8 AIROB, Associazione Italiana per la Ricerca Oncologica di Base, 35128 Padova, Italy \\ * Correspondence: taaheri.yasaman@gmail.com (Y.T.); javad.sharifirad@gmail.com (J.S.-R.); \\ chocs@ha.org.hk (W.C.C.); raffaele.pezzani@unipd.it (R.P.)
}

Received: 9 September 2019; Accepted: 16 October 2019; Published: 18 October 2019

check for updates

\begin{abstract}
Plants are a great and irreplaceable source of medicines, fuel, food, energy and even cosmetics. Since prehistory, humans have learned to use plants for survival, growth and proliferation and still today it relies on natural and cultivated vegetables for food and the source of novel compounds with pharmacological activity. Not only herbs and flowers, but also trees are used. Indeed, Erythrina suberosa Roxb. is a deciduous tree of the family Fabaceae, common in Southeast Asia. In India, E. suberosa is called the "corky coral tree" or simply the "Indian coral tree", given its peculiar red-orange flowers that can flower throughout the year and its corky irregular bark covered by prickles. It is a plant commonly used as an ornamental tree, but it also holds ethnopharmacological and socioeconomic uses. This article explored phytobiological features of E. suberosa, analysing its taxonomy, examining its traditional and common uses and investigating its bioactive components and pharmacological properties.
\end{abstract}

Keywords: Erythrina suberosa; Erythrina genus; phytopharmacology; anticancer

\section{Introduction}

Erythrina suberosa Roxb. is a deciduous tree of medium size (about $10 \mathrm{~m}$ ) belongs to the family Fabaceae. Native of Punjab region and called "Pangra" [1], it is widely used in Pakistan and India as an ornamental tree. E. suberosa belongs to the genus Erythryna which comprises more than 100 species: according to Da Silva, et al. [2], the Erythryna genus includes 120 species distributed in Tropical and Subtropical regions. The appellation "coral tree or flame tree" is commonly given to the Erythryna genus because of its red flowers and because the branches can resemble the shape of sea coral [3]. Furthermore, the origin of the name comes from the Greek "erythros", which truly means "red". According to the Annotated Checklist of the Flowering Plants of Nepal [4] and ILDIS [5], E. suberosa can be used as a synonym for Erythrina glabrescens (Prain) R. Parker. This review article focuses on the species E. suberosa, analysing its taxonomy, traditional and common uses, bioactive components 
and pharmacological properties. Many other works have analyzed the properties and effects of the Erythrina genus and we suggest that the reader examine subsequent pivotal reviews [6,7].

\section{Taxonomy and Morphologic Description}

E. suberosa belongs to the kingdom of Plantae (Plants), division of Magnoliophyta (flowering plants), class of Magnoliopsida (Dicotyledons), order of Fabales, family of Fabaceae (Legume family), subfamily of Papilionoideae, genus of Erythrina (L.), species suberosa (Roxb.) [8]. In addition to the accepted name, E. suberosa presents many nonpreferred scientific names, such as Erythrina alba Wight\& Arn., Micropteryx sublobata (Roxb.) Walp., Erythrina glabrescens (Prain) R.Parker, Erythrina maxima Wight \& Arn., Erythrina stricta var. suberosa (Roxb.), Erythrina sublobata Roxb., and Micropteryx suberosa (Roxb.) Walp. E. suberosa is commonly referred to in Hindi as "Pangra", in Malayalam as "Mullumurukku", while in Tamil it is referred to as "Mullumurungu" [9].

The E. suberosa tree is of medium size (can grow up to $10 \mathrm{~m}$ high) and has a grey, corky, deeply cracked bark (Figure 1). The branches have prickles, while branchlets are tomentose and vigorous [10]. The flowers are of bright scarlet, are $4 \mathrm{~cm}$ long, bisexual, and placed in axillary and terminal racemes which blossom February-April. The leaves are trifoliate and alternate with a leaflet size of $15-10 \mathrm{~cm} \times 6-12 \mathrm{~cm}$, a rhomboid-oval shape, and are glabrous above and woolly pubescent underneath. The fruits are pods that can easily reach $15 \mathrm{~cm}$ and fructify April-May. There are normally 2-5 seeds per fruit and these can be subdivided into two types: (a) light brown (b) dark reddish-brown seeds. This colour dimorphism of the seeds can be seen within a single pod, not only in an individual plant. They have a shape of an ellipsoid (reniform), and they are smooth and glittering.

E. suberosa is widely distributed in plain regions of India (common around Pune), Nepal, Bhutan, Burma, Thailand and Vietnam, sporadically on hills and on moist slopes [11,12]. Although the number of Erythrina species is large worldwide, in India there is a limited number of plants belonging to Erythrina genus, such as E. suberosa, E. fusca Lour., E. resupinata Roxb., E. stricta Roxb., E. arborescens Roxb., E. subumbrans (Hassk.) Merr., and E. variegata L. (syn. E. indica Lam.), which are all wild species. There are also cultivated species: E. crista-galli L., E. corallodendrum L., E. mitis Jacq., E. poeppigiana (Walp.) O.F. Cook., and E. blakei Parker [13]. It is notable that all of these reported species are also present in Andhra Pradesh, Pakistan and Nepal.

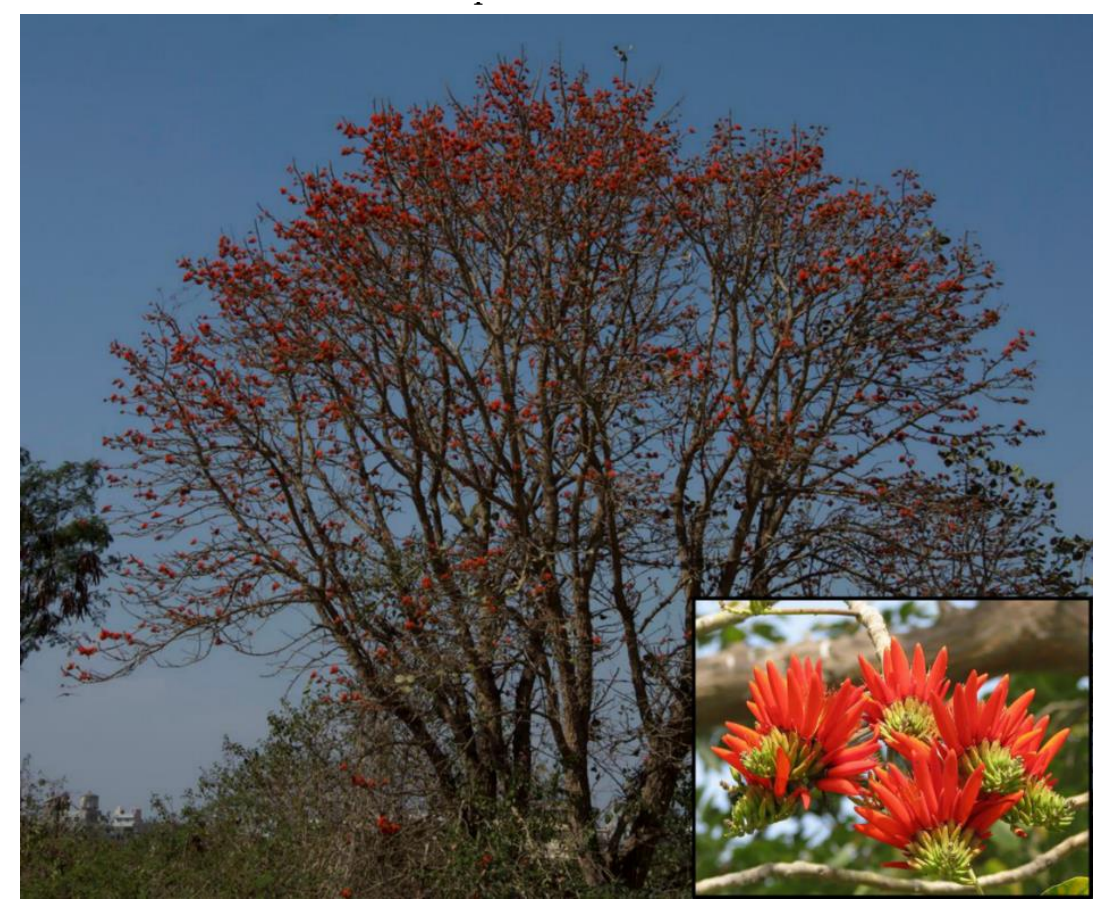

Figure 1. Erythrina suberosa Roxb. tree and flowers. 


\section{Traditional and Common Uses}

Besides being an ornamental tree, E. suberosa is traditionally used in the Southeast of Asia as an ethnopharmacological source for numerous preparations.

In an ancient Indian traditional medicine called "Siddha", E. suberosa has been used in many habitual formulations involving the consumption of all the plant, such as radix, leaves, bark, and flowers. In particular, radix can be used as emmenagogue, while leaves can be used as cathartics, anthelmintics, galactogenics and diuretics [14]. Paste made from the leaves can be applied to swellings and boils, given its antiseptic and anti-inflammatory effects [14]. Stem bark can have expectorant, bronchodilator, laxative, spasmolytic, anthelmintic, diuretic, and emmenagogue properties; indeed, bark decoction is used for dysentery, worm infestation and as eye lotion in opthalmia [15]. Moreover, the fresh juice is used topically for ulcers, wounds and sores [15]. Flowers are used to reduce nausea, for ear troubles and the aqueous extract can be mixed with Hibiscus rosa-sinensis L. as a soothing drink with a refreshing and relaxing effect during the summer season [16]. Conversely, the seeds are poisonous if ingested, but they are commonly used outside of the pharmacological field in different objects such as necklaces, rosaries and good-luck charms [17].

In traditional Tibetan medicine, E. suberosa flowers play a fundamental role in treating numerous fever-producing diseases, such as those afflicting the liver, lungs and heart [14].

E. suberosa is also employed in veterinary medicine. Indeed, bark ashes are mixed with coconut oil and applied to pustules, boils and wounds in cattle as an antiseptic; bark decoctions (stem without bark, crushed and extracted) are applied to swelling or injuries in animals [18]. It is reported that stem bark can be used as a fish poison: in addition, E. suberosa can have the ability to tint clothes (as a dark brown dye), it is used for the manufacture of cork and the wood from E. suberosa is employed in the production of light boxes and as fuel [18].

\section{Bioactive Components and Phytoconstituents}

Different works have analyzed the composition of E. suberosa. From the wood of E. suberosa, Tanaka [19] isolated two isoflavones-erysubins A and B-and more recently in 2001, the same group found two prenylated isoflavones, with hydroxyisopropyldihydrofuran moiety, senegalensin and its regioisomer euchrenone $b_{10}$ in the wood of E. suberosa var. glabrescence [20] (Figure 2). In addition, from the bark of E. suberosa, a more recent work has isolated four different metabolites, i.e., $\alpha$-hydroxyerysotrine, $4^{\prime}$-methoxylicoflavanone (MLF), alpinumisoflavone (AIF) and wighteone [21]. Furthermore, the roots of E. suberosa contain different alkaloids as well as prenylated flavonones and isoflavonoids, i.e., erysubin C (a pterocarpan with a formile group), erysubins D-E-F and cristacarpin [20,22]. Moreover, from the seeds of E. suberosa (which contain a high number of organic acids, alkaloids and steroids), Singh and Chawla [23] isolated different alkaloids such as erytraline, erysodine, erysotrine and hypaphorine. For the first time, erysotrine (usually found as a product of other eryso-alkaloids), an alkaloid present in many plants, was found to occur naturally in E. suberosa [22]. Also, it has been shown that the oil extracted from the seeds contains fatty acids such as sitosterol, stigmasterol, campesterol and cholesterol [22]. Again, in the seeds, Bhattacharyya, et al. [24] discovered the presence of D-galactose-binding lectins.

From the leaves of E. suberosa, similarly to the seeds, erysotrine was isolated and characterized [25], while from the flowers (crude extract), tannins, anthraquinones, sterols, terpenes, flavonoids, saponins and phenolic compounds were isolated [16]. 


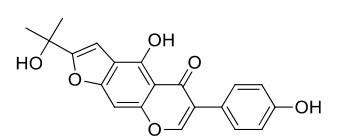

Erysubin A

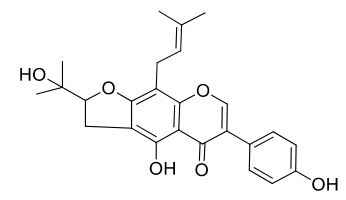

Euchrenone $b_{10}$

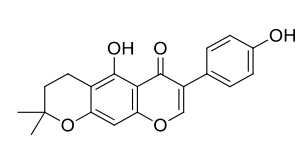

Alpinumisoflavone

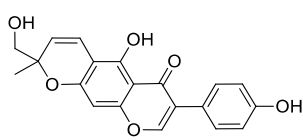

Erysubin B

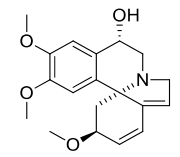

$\alpha$-hydroxyerysotrine

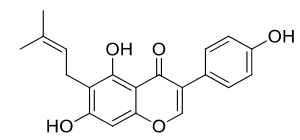

Wighteone

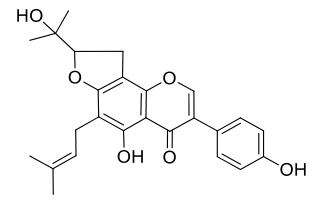

Senegalensin

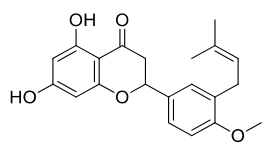

4'-methoxylicoflavanone

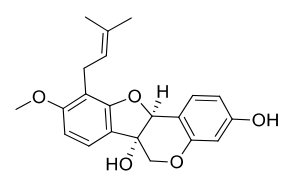

Cristacarpin

Figure 2. Chemical structures of selected compounds isolated from Erythrina suberosa Roxb.

\section{Pharmacological Properties}

To our knowledge, no work has examined the effects of E. suberosa or the genus Erythryna on humans, although many studies were conducted on preclinical models. Most of the works in the literature deal with the anticancer properties of E. suberosa, spanning from haematological to solid malignancies and from human derived cancer cells to mouse models [26]. Dhar, et al. [27] first evaluated the effects of a water-ethanol extract (1:1) of E. suberosa leaves (and many other Indian plants). They showed that $E$. suberosa could have anti-neoplastic and potential pharmacological activity in Sarcoma 180 (Mus musculus sarcoma), but no other indications were added [27]. Another work demonstrated that E. suberosa leaf extract had no anticancer effects on L1210 cells (Mus musculus skin lymphocytic leukemia) [21] probably underlining that different extraction methods could influence pharmacological properties.

Additionally, human cancer cell lines were investigated: HL60 (human promyelocytic leukemia) cells were tested with E. suberosa bark ethanolic extract [28]. Cell proliferation was inhibited in a dose- and time-dependent manner and the cell cycle was modulated by an increase in subG0/G1 cell phase. Moreover, an increase in cytosolic cytochrome $\mathrm{C}$ was shown with a concomitant intrinsic apoptosis pathway activation, with the stimulation of caspases 9 and 3, but not caspase 8 . The authors suggested that $E$. suberosa extract could induce a mitochondria-mediated intrinsic apoptotic pathway and potentially could have a role in treating human leukemia.

Similarly, Kumar, Pathania, Saxena, Vishwakarma, Ali and Bhushan [3] isolated four metabolites from E. suberosa bark extract (MLF, AIF, wighteone, $\alpha$-hydroxyerysotrine) and tested them on HL60 cancer cells. They showed that both MLF and AIF demonstrated the most potent cytotoxicity with $\mathrm{IC}_{50}$ of $\sim 20 \mu \mathrm{M}$ in HL60 cells and could induce apoptosis through inhibition of NF-kB factor (through the signal transducer of activation (STAT) pathway) [3]. Moreover, wighteone, an isoflavone derived from E. suberosa stem bark as mentioned above, demonstrated anticancer effects in MCF-7 HER2-positive cells (human mammary cancer cells) mediated by the heat shock protein 90 (HSP90), again increasing apoptosis and reducing cell proliferation [29]. Is it notable that wighteone can be found in different plants: Cudrania tricuspidata (Carrière) Bureau, Ficus tikoua Bur., Maclura pomifera (Raf.) C.K. Schneid. [30,31] and in different species of the genus Erythrina: stricta, fusca, poeppigiana and variegata [32-35]. 
Furthermore, a work on cristacarpin, a prenylated pterocarpan found in E. suberosa bark, confirmed that both PANC-1 (human pancreatic cancer cells) and MCF-7 cells were sensitive to this compound. Indeed, cell viability was decreased without toxic effects on non-cancer cell lines, such as HUVEC (human endothelial cells) and BPH-1 cells (human benign prostatic hyperplasia cells) [36]. In addition, the authors showed that cristacarpin, in an in vivo experiment with a 4T1 allograft mouse mammary carcinoma model, could prevent tumor growth by inducing premature senescence through both G1 phase blocking and ROS-dependent activation of p21/waf1. Notably, cristacarpin can also be found in Erythrina burana Chiov. [37-39]. More recently, E. suberosa leaf aqueous extract was incorporated into silver nanoparticles and then used in an osteosarcoma cancer cell line (A-431) [40]. The authors discovered that A-431 cell viability was decreased after treatment with this preparation, that also possessed anti-microbial properties, given its strong effects against different pathogenic bacteria and fungi [40].

In addition to cancer studies, E. suberosa was tested using different disease models. A work of Serrano, Batista, Bolzani, Santos, Nogueira, Nunes-de-Souza, Latif and Arfan [12] showed that acute treatment per os with the E. suberosa alkaloids erysodine and erysothrine produced anxiolytic-like effects in mice tested with two widely used anxiety assays (the elevated plus-maze and the light-dark transition model). Also, the bronchodilator and spasmolytic properties of E. suberosa were explored. Indeed, a methanolic crude extract of E. suberosa flowers was tested on isolated rabbit jejunum and isolated rabbit tracheal preparations. It was demonstrated that the extract could halt $\mathrm{Ca}^{2+}$ channels and showed antioxidant activities, which was revealed by strong scavenging activity on DPPH (2,2-difenil-1-picrylhydrazyl) free radicals. With this last work, the traditional use of E. suberosa has been concretely substantiated, however these results should be confirmed using higher models [16].

\section{Concluding Remarks}

From its pharmacological properties, phytoconstituents, traditional and common uses of E. suberosa, we found that different extracts as well as the isolated compounds can have a robust anticancer biological activity. Still, many efforts should be taken before translating the E. suberosa potential into medicinal remedies. There are just a few preclinical studies analysing the effects of $E$. suberosa, more extensive studies are needed (Figure 3).

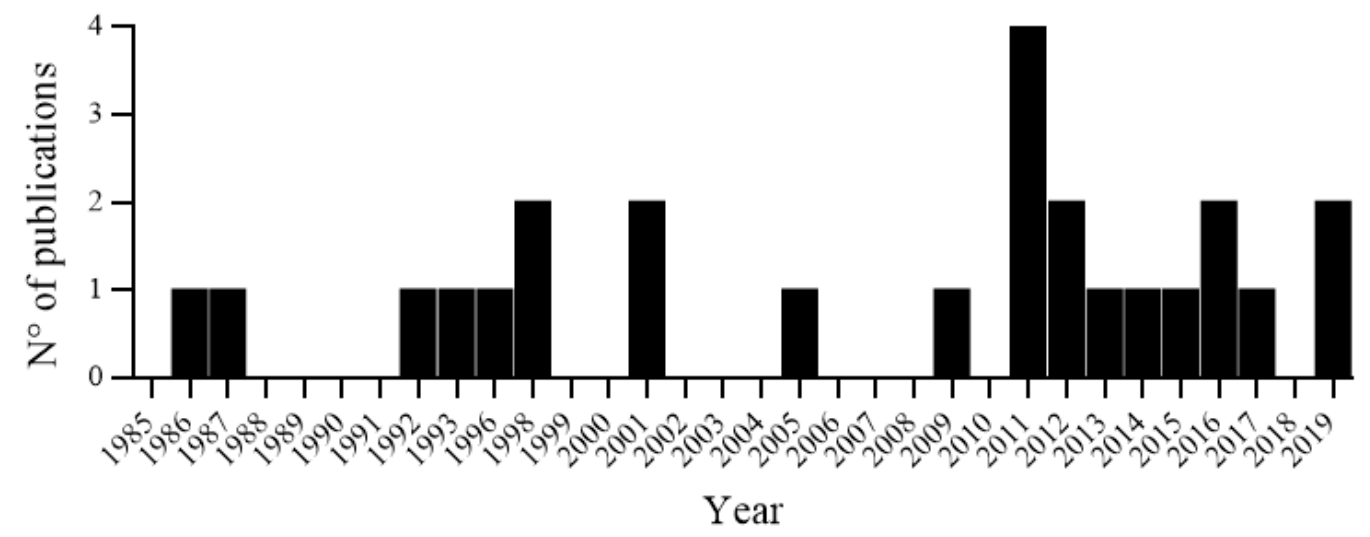

Figure 3. Histogram of publications per year for Erythrina suberosa Roxb. from 1985 to 2019 (accessed on 7 October 2019, adapted from Web of Science, https://www.webofknowledge.com).

This fact should be intended as a concrete stimulus for researchers and clinicians, not a limitation in E. suberosa studies. It is expected that new resources, capabilities and energy should be provided for a more in-depth study of E. suberosa.

Author Contributions: All authors contributed to the manuscript. Conceptualization, F.P. and R.P.; validation investigation, resources, data curation, writing - all authors; review and editing, F.P., Y.T., J.S.-R., M.M., W.C.C., and R.P., all the authors read and approved the final manuscript. 
Funding: This research received no external funding.

Acknowledgments: This work was partially supported by CONICYT PIA/APOYO CCTE AFB170007.

Conflicts of Interest: The authors declare no conflict of interest.

\section{References}

1. Chauhan, P.; Saxena, V.K. A New Prenylated Flavanone from Erythrina suberosa Roots. Planta Med. 1987, 53, 221-222. [CrossRef] [PubMed]

2. Da Silva, M.M.B.; Santana, A.S.C.O.; Pimentel, R.M.M.; Silva, F.C.L.; Randau, C.P.; Soares, L.A.L. Anatomy of leaf and stem of Erythrina velutina. Rev. Bras. Farmacogn. Braz. J. Pharmacogn. 2013, 23, 200-206. [CrossRef]

3. Kumar, S.; Pathania, A.S.; Saxena, A.K.; Vishwakarma, R.A.; Ali, A.; Bhushan, S. The anticancer potential of flavonoids isolated from the stem bark of Erythrina suberosa through induction of apoptosis and inhibition of STAT signaling pathway in human leukemia HL-60 cells. Chem. Biol. Interact. 2013, 205, 128-137. [CrossRef] [PubMed]

4. EFLORAS. Available online: http://www.efloras.org/ (accessed on 11 November 2018).

5. International Legume Database Information. Available online: http://www.ildis.org (accessed on 10 November 2018).

6. Rambo, D.F.; Biegelmeyer, R.; Toson, N.S.B.; Dresch, R.R.; Moreno, P.R.H.; Henriques, A.T. The genus Erythrina L.: A review on its alkaloids, preclinical, and clinical studies. Phytother. Res. 2019, 33, 1258-1276. [CrossRef] [PubMed]

7. Fahmy, N.M.; Al-Sayed, E.; El-Shazly, M.; Singab, A.N. Comprehensive review on flavonoids biological activities of Erythrina plant species. Ind. Crops Prod. 2018, 123, 500-538. [CrossRef]

8. EOL. Encyclopedia of Life. Available online: http://eol.org/pages/643183/names/common_names (accessed on 10 November 2018).

9. India Biodiversity Portal. Erythrina suberosa Roxb. Available online: http://indiabiodiversity.org/species/ show/31297 (accessed on 9 November 2018).

10. Kumar, A.; Lingadurai, S.; Jain, A.; Barman, N.R. Erythrina variegata Linn: A review on morphology, phytochemistry, and pharmacological aspects. Pharmacogn Rev. 2010, 4, 147-152. [CrossRef]

11. Open_data_Keystone_Fundation. Flora of the Nilgiris. Available online: http://opendata.keystonefoundation.org/erythrina-suberosa-roxb (accessed on 9 November 2018).

12. Serrano, M.A.R.; Batista, A.N.d.L.; Bolzani, V.d.S.; Santos, L.d.Á.; Nogueira, P.J.d.C.; Nunes-de-Souza, R.L.; Latif, A.; Arfan, M. Anxiolytic-like effects of erythrinian alkaloids from Erythrina suberosa. Quím. Nova 2011, 34, 808-811.

13. Sanjappa, M. Legumes of India; Bishen Singh Mahendra Pal Singh: Uttarakhand, India, 1992.

14. Khan, A.S. Medicinally Important Trees; Springer International Publishing: Berlin, Germany, 2017.

15. Araújo-Júnior, J.X.d.; de Oliveira, M.S.G.; Aquino, P.G.V.; Alexandre-Moreira, M.S.; Sant'Ana, A.E.G. A Phytochemical and Ethnopharmacological Review of the Genus Erythrina; InTech: London, UK, 2012.

16. Janbaz, K.H.; Nisar, U.; Ashraf, M.; Qadir, M.I. Spasmolytic, bronchodilatory and antioxidant activities of Erythrina superosa Roxb. Acta Poloniae Pharm. 2012, 69, 1111-1117.

17. Khan, D.; Sahito, Z.A.; Javed Zaki, M.; Shahid Shaukat, S. Axial dimensions of pods and seeds and within-pod-allocation of phytomass and seed packaging cost in Erythrina suberosa Roxb. (Papilionaceae). Int. J. Bio. Biotechnol. 2014, 11, 191-206.

18. Quattrocchi, U. CRC World Dictionary of Medicinal and Poisonous Plants: Common Names, Scientific Names, Eponyms, Synonyms, and Etymology; CRC Press: Boca Raton, FL, USA, 2016.

19. Tanaka, H.T.T.; Etoh, H.; Watanabe, N.; Ahmad, M.; Qurashi, I.; Rehan Khan, M. Two New Isoflavones from Erythrina suberosa var. glabrescences. Heterocycles 1998, 48, 2669-2675. [CrossRef]

20. Tanaka, H.; Doi, M.; Etoh, H.; Watanabe, N.; Shimizu, H.; Hirata, M.; Ahmad, M.; Qurashi, I.; Khan, M.R. Revised structures for senegalensin and euchrenone b (10). J. Nat. Prod. 2001, 64, 1336-1340. [CrossRef] [PubMed]

21. Singh, H.; Chawla, A.S. Investigation of Erythrina spp. V. study of Erythrina suberosa leaves. Planta Med. 1971, 19, 378-379. [CrossRef] [PubMed]

22. Singh, H.; Chawla, A.S. Erythrina sp. 3. Chemical constituents of Erythrina suberosa Roxb. seeds. J. Pharm. Sci. 1970, 59, 1179-1182. [CrossRef] [PubMed] 
23. Singh, H.; Chawla, A.S. Isolation of erysodine, erysotrine and hypaphorine from Erythrina suberosa Roxb. seeds. Experientia 1969, 25, 785. [CrossRef]

24. Bhattacharyya, L.; Das, P.K.; Sen, A. Purification and properties of D-galactose-binding lectins from some Erythrina species: Comparison of properties of lectins from E. indica, E. arborescens, E. suberosa, and E. lithosperma. Arch. Biochem. Biophys. 1981, 211, 459-470. [CrossRef]

25. Miana, G.A.; Ikram, M.; Sultana, F.; Khan, M.I. The isolation and characterization of erysotrine from the leaves of Erythrina suberosa. Lloydia 1972, 35, 92-93.

26. Aye, M.M.; Aung, H.T.; Sein, M.M.; Armijos, C. A Review on the Phytochemistry, Medicinal Properties and Pharmacological Activities of 15 Selected Myanmar Medicinal Plants. Molecules 2019, 24, 293. [CrossRef]

27. Dhar, M.L.; Dhar, M.M.; Dhawan, B.N.; Mehrotra, B.N.; Ray, C. Screening of Indian plants for biological activity: I. Indian J. Exp. Biol. 1968, 6, 232-247.

28. Agrawal, S.K.; Agrawal, M.; Sharma, P.R.; Gupta, B.D.; Arora, S.; Saxena, A.K. Induction of apoptosis in human promyelocytic leukemia HL60 cells by an extract from Erythrina suberosa stem bark. Nutr. Cancer 2011, 63, 802-813. [CrossRef]

29. Cao, Z.W.; Zeng, Q.; Pei, H.J.; Ren, L.D.; Bai, H.Z.; Na, R.N. HSP90 expression and its association with wighteone metabolite response in HER2-positive breast cancer cells. Oncol. Lett. 2016, 11, 3719-3722. [CrossRef]

30. Yin, Y.Z.; Wang, R.S.; Chen, R.D.; Qiao, L.R.; Yang, L.; Wang, C.M.; Dai, J.G. Chemical constituents from cell suspension cultures of Cudrania tricuspidata. J. Chin. Mat. Med. 2012, 37, 3734-3737.

31. Wei, S.; Wu, W.; Ji, Z. New antifungal pyranoisoflavone from Ficus tikoua Bur. Int. J. Mol. Sci. 2012, 13, 7375-7382. [CrossRef] [PubMed]

32. Akter, K.; Barnes, E.C.; Loa-Kum-Cheung, W.L.; Yin, P.; Kichu, M.; Brophy, J.J.; Barrow, R.A.; Imchen, I.; Vemulpad, S.R.; Jamie, J.F. Antimicrobial and antioxidant activity and chemical characterisation of Erythrina stricta Roxb. (Fabaceae). J. Ethnopharmacol. 2016, 185, 171-181. [CrossRef] [PubMed]

33. Innok, P.; Rukachaisirikul, T.; Suksamrarn, A. Flavanoids and pterocarpans from the bark of Erythrina fusca. Chem. Pharm. Bull. 2009, 57, 993-996.

34. Djiogue, S.; Halabalaki, M.; Alexi, X.; Njamen, D.; Fomum, Z.T.; Alexis, M.N.; Skaltsounis, A.L. Isoflavonoids from Erythrina poeppigiana: Evaluation of their binding affinity for the estrogen receptor. J. Nat. Prod. 2009, 72, 1603-1607. [CrossRef]

35. Xiaoli, L.; Naili, W.; Sau, W.M.; Chen, A.S.; Xinsheng, Y. Four new isoflavonoids from the stem bark of Erythrina variegata. Chem. Pharm. Bull. 2006, 54, 570-573. [CrossRef]

36. Chakraborty, S.; Rasool, R.U.; Kumar, S.; Nayak, D.; Rah, B.; Katoch, A.; Amin, H.; Ali, A.; Goswami, A. Cristacarpin promotes ER stress-mediated ROS generation leading to premature senescence by activation of p21 waf-1. Age 2016, 38, 62. [CrossRef]

37. Tanaka, H.; Hattori, H.; Oh-Uchi, T.; Sato, M.; Sako, M.; Tateishi, Y.; Rizwani, G.H. Three new isoflavanones from Erythrina costaricensis. Nat. Prod. Res. 2009, 23, 1089-1094. [CrossRef]

38. Tanaka, H.; Hattori, H.; Oh-Uchi, T.; Sato, M.; Yamaguchi, R.; Sako, M.; Tateishi, Y. Two new isoflavanones from Erythrina costaricensis. J. Asian Nat. Prod. Res. 2008, 10, 983-987. [CrossRef]

39. Dagne, E.; Gunatilaka, A.A.; Kingston, D.G.; Alemu, M.; Hofmann, G.; Johnson, R.K. Two bioactive pterocarpans from Erythrina burana. J. Nat. Prod. 1993, 56, 1831-1834. [CrossRef]

40. Mohanta, Y.K.; Panda, S.K.; Jayabalan, R.; Sharma, N.; Bastia, A.K.; Mohanta, T.K. Antimicrobial, Antioxidant and Cytotoxic Activity of Silver Nanoparticles Synthesized by Leaf Extract of Erythrina suberosa (Roxb.). Front. Mol. Biosci. 2017, 4, 14. [CrossRef] [PubMed]

(C) 2019 by the authors. Licensee MDPI, Basel, Switzerland. This article is an open access article distributed under the terms and conditions of the Creative Commons Attribution (CC BY) license (http://creativecommons.org/licenses/by/4.0/). 